\title{
Differential cellular immune response in inductive and effectors sites after oral administration of quercetin
}

\author{
E. M. Insani ${ }^{1}$, A. C. Mignaqui ${ }^{1}$, A. A. Pazos $^{1}$, M. E. Roux ${ }^{2,4}$ and N. H. Slobodianik ${ }^{3}$ \\ ${ }^{1}$ Institute of Food Technology (INTA), ${ }^{2}$ Laboratory of Mucosal Immunity, Department of Cellular Biology, ${ }^{3}$ Department of \\ Nutrition, School of Pharmacy and Biochemistry, University of Buenos Aires and ${ }^{4}$ CONICET, Buenos Aires, Argentina
}

The aim of this research was to compare the immune response after oral administration of quercetin ${ }^{(1)}$ in mesenteric lymphoid nodes (MLN; inductive site) and lamina propria of intestinal villi (IV; effector site) ${ }^{(2)}$.

An experimental model was used to evaluate the effect of protein malnutrition and allergic response. Weanling rats of Wistar strain were fed a protein-free diet until they lost $25 \%$ of their initial body weight. Re-feeding was performed by the administration of an experimental diet containing $20 \%$ casein as the only source of protein (Re-nourished group; R). Other experimental groups received this experimental diet plus quercetin $(\mathrm{R}+\mathrm{Q} 1$ or $\mathrm{R}+\mathrm{Q} 2)(\mathrm{Q} 1=140 \mu \mathrm{g} / \mathrm{kg}$ body weight per $\mathrm{d}$; $\mathrm{Q} 2=280 \mu \mathrm{g} / \mathrm{kg}$ body weight per d; mean value), added to drinking water during $40 \mathrm{~d}$. Three well-nourished groups were used as normal controls $(\mathrm{C})$ which were fed with standard commercial diet or the same diet plus quercetin $(\mathrm{C}+\mathrm{Q} 1$ and $\mathrm{C}+\mathrm{Q} 2)$. The MLN and small intestine were removed and properly processed, the last ones by Saint-Mariés technique ${ }^{(3)}$. IgE + B-cells were measured (Indirect Immunofluorescent Assay). The animal protocol was approved by the ethical committee of the University of Buenos Aires.

Results showed that in MLN R group presented higher \% of IgE + B-cells compared with C $(42 \pm 2 ; 28 \pm 2)(P<0.0001)$. This value diminished to $17 \pm 2$ in $\mathrm{R}+\mathrm{Q} 1$, normalising the values under the normal control, $\mathrm{C}$. With double dose of quercetin, $\mathrm{R}+\mathrm{Q} 2$ was statistically lower than $\mathrm{R}$ but this dose resulted less efficient to diminish \% of $\operatorname{IgE}+\mathrm{B}$-cells $(\mathrm{R}+\mathrm{Q} 2=34 \pm 2)$ (Figs. 1 and 2$)$.

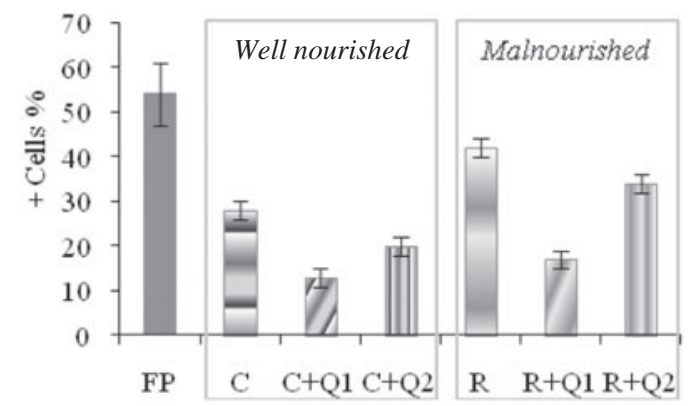

Fig. 1. IgE + B-cells in MLN

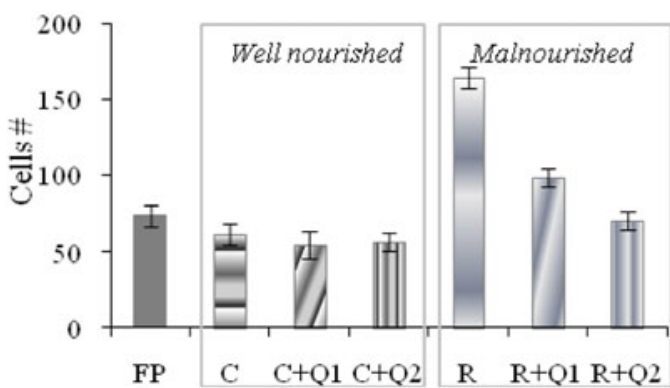

Fig. 2. $\mathrm{IgE}+\mathrm{B}$-cells in IV.

In IV, the effector site of the immune response, $\mathrm{R}$ group presented the highest number of IgE $+\mathrm{B}$-cells reaching to $165 \pm 7(\mathrm{C} 62 \pm 7$; $P<0.0001)$. In this case, double dose of quercetin was more efficient for lowering IgE + B-cells compared with $\mathrm{Q} 1(\mathrm{R}+\mathrm{Q}, 2 \mathrm{71} \pm 6$; $\mathrm{R}+\mathrm{Q} 1,99 \pm 6)$.

In conclusion, quercetin intake presented differential effect for IgE + B-cells related to inductive or effectors sites of immune response. These findings have to be taken into account to describe the effect of bioactive compound of nutritional interest.

1. Insani EM, Mignaqui AC, Pazos AA et al. (2010) Proc Nutr Soc 69(OCE3), E286.

2. Nagler-Anderson C (2001) Nat Rev/Immunol 1, 59-67.

3. Saint Marie G (1962) J Histochem Cytochem 10, 250-256. 